\title{
Preschool Teachers' Practices of ICT-Supported Early Language and Mathematics
}

\author{
Kleopatra Nikolopoulou \\ Department of Early Childhood Education, School of Education, National and Kapodistrian University of Athens, Athens, Greece \\ Email: klnikolop9@yahoo.gr, klnikolop@ecd.uoa.gr
}

How to cite this paper: Nikolopoulou, K. (2020). Preschool Teachers' Practices of ICTSupported Early Language and Mathematics. Creative Education, 11, 2038-2052. https://doi.org/10.4236/ce.2020.1110149

Received: September 25, 2020

Accepted: October 20, 2020

Published: October 23, 2020

Copyright $\odot 2020$ by author(s) and Scientific Research Publishing Inc. This work is licensed under the Creative Commons Attribution International License (CC BY 4.0).

http://creativecommons.org/licenses/by/4.0/ (c) (i) Open Access

\begin{abstract}
Young children interact with a wide range of digital technologies in their everyday lives and become competent users of computers, tablets, etc. The purpose of this study was to investigate preschool teachers' practices regarding ICT-supported early language and mathematics learning. The participants were eight teachers and data were collected via semi-structured interviews, in Greece. The most commonly reported purposes for ICT usage in preschool classes were searching for information, as a supplementary-supportive tool and for displaying educational video/pictures. The learning activities carried out in early language learning via ICT included displaying of pictures/ drawings, writing a word/name/date, practicing letters, connecting words to their sound/image and phonological awareness (for familiarization with the written word, oral language, enhancement of vocabulary etc). The learning activities carried out in early mathematics with the support of ICT included serialization-sorting of objects, learning of time and space concepts, familiarization with numbers, classification, matching, as well as activities with shapes, colors, and memory cards. Teachers' practices have implications for teacher professional development.
\end{abstract}

\section{Keywords}

Early Childhood Education, ICT, Language, Mathematics, Classroom Practices, Preschool

\section{Introduction}

Today's young children interact with a wide range of digital technologies (ICT) in their everyday lives and become competent users of devices, such as computers, tablets, video game consoles, digital video and communication based devices, without any formal instruction (Stephen \& Edwards, 2018; Ofcom, 2019; Ni- 
kolopoulou et al., 2019). Lately, mobile technology has become popular among young children in both informal and formal educational environments (Nikolopoulou, 2019, 2020; Papadakis \& Kalogiannakis, 2020; Dorouka et al., 2020). Research studies throughout the years (e.g., Clements, 1994; Clements \& Sarama, 2003; Stephen \& Plowman, 2003; McKenney \& Voogt, 2012; Nikolopoulou, 2018) have indicated that ICT/technology can be used as a tool to support children's learning and development, a tool which can assist communication, collaboration, creativity and language development in young children. Studies indicated a positive impact of digital technologies' usage on children's literacy skills (Neumann, 2018; Gray et al., 2017), mathematical skills (Gray et al., 2017; Papadakis et al., 2018; Outhwaite et al., 2017), science, problem-solving, and self-efficacy (Herodotou, 2017).

Fewer studies reported on teachers' practices regarding ICT supported-mediated language and mathematics learning in early childhood education (ECE) settings (Nikolopoulou, 2014a; Romero-Tena et al., 2020). The purpose of this study was to investigate early childhood teachers' practices when ICT is used to support early language and mathematics learning in kindergarten settings. Investigating teachers' practices is important, because these affect the effectiveness of technology usage in the classroom and consequently children's engagement, interaction and learning with technologies (Neumann et al., 2018). For the purpose of this paper, the term ICT is used as synonymous to the term digital technology (including mobile technology). Apart from computer software, a number of products that incorporate some aspects of ICT are available to young children (such as electronic musical keyboards, programmable interactive toys and digital cameras), while lately mobile technologies and, in particular, tablets are very popular among young children (Stephen \& Edwards, 2018; Nikolopoulou, 2020). The terms early childhood education, preschool and kindergarten are used as synonymous, indicating the formal educational settings that attend, in most countries, children aged between 3 and 6.5 years old. Before the literature review section, the Greek context is briefly described.

In Greece, all public kindergartens are predominantly equipped with one computer (rarely two or three) with a printer; some classrooms are also equipped with interactive whiteboards and overhead projectors, while ICT use is gradually spreading in formal ECE settings (Nikolopoulou, 2019). Funding is limited in public kindergartens, while the financial situation is somewhat better in private sector. Regarding ICT teacher training, an increasing number of kindergarten teachers attend the large in-service teacher training programme on the pedagogical uses of ICT (B' level training); "In-service training of teachers in the utilization and application of digital technologies in the teaching practice" aims to equip teachers with appropriate skills such as to design learning activities with ICT tools and to implement-integrate technology effectively in their everyday teaching practices. The first phase of the programme (A' level) included training in technical skills and has been attended by the majority of early childhood 
teachers. The official curriculum for kindergarten (P.I, 2011) recommends the use of software (educational and general-purpose) and internet services, to be integrated into day-to-day kindergarten activities as a teaching and learning tool, as an experimentation and problem-solving tool, and as an information management tool; to promote digital literacy, communication and cooperation. There are some general guidelines as to the integration of technology/ICT as supportive tool across different subjects; however, no reference is made to mobile technology.

\section{Literature Review}

Investigating early childhood teachers' reasons as to why they use computers is essential because their reasons affect their classroom practices. A study in Greece (Nikolopoulou, 2014a) investigated computer use and integration in 17 kindergartens in Greece and indicated that the most frequently reported purposesreasons for computer use regarded the acquisition/development of language and fine motor skills, as an incentive for learning, as a supervisory tool, and for entertainment (e.g., playing games). Romero-Tena et al. (2020) investigated how preschool teachers made use of ICT, in Spain. ICT was used to prepare classroom work (planning, classroom posters) and as a classroom support learning tool (routines, games, to record audios etc). It was also found that teachers used ICT for occasional administrative tasks, while ICT use for communication and exchange of ideas, as well as pupil assessment, was limited.

Language and mathematics learning are among the core subjects for children's learning at early stages. For example, early language skills provide the foundation for future reading, writing, speaking and listening ability, while oral language skills (the ability to produce/comprehend spoken language) such as vocabulary and word knowledge are strong predictors of later reading skills (Neumann, 2020). Also, early mathematical skills such as matching, sorting and seriation constitute the foundation for more advanced math skills/concepts. Matching (identification of similar objects based on their common properties) and sorting are important early math skills that help in classification of objects, while seriation skills (the ability to arrange objects in order/series by size) often help children develop problem-solving skills.

With regard to the impact of ICT (digital technology) on early language and mathematics learning, research indicated the impact on children's literacy development (Herodotou, 2017), on phonological awareness and counting (Reeves et al., 2017), on learning of mathematical concepts (understanding numbers, counting) (Kucirkova et al., 2014), and on basic math skills such as classification, seriation and counting (Zaranis \& Valla, 2019). For example, Zaranis \& Valla (2019) investigated the implementation of a software application for comparison, classification, counting, seriation and general knowledge of numbers with tablet computers, in Greek kindergartens. Their results supported a positive link between children's early numeracy competence and the integration of tablet 
computers in teaching and learning numbers.

A pilot project on the use of mobile devices in kindergartens, in North Ireland (Gray et al., 2017) evaluated the use of tablets for developing literacy and numbering skills. Mobile technology has been found to complement traditional teaching practices rather than replace them. In general, there has been a positive impact on reading and writing. Teachers reported that the use of tablets in class enhanced children's communication skills, especially when children shared tablets, there was a high level of discussion. Also, Lu et al. (2017), in the USA, indicated that early childhood teacher-directed approaches focused on using iPads to practice basic literacy skills.

A few studies examined the influence of the same educational mathematical software on different platforms, on children's learning. Papadakis et al. (2016) investigated and compared the influence of using computers and tablets towards the development of mathematical competence in early childhood education. It was shown that teaching with tablets compared to teaching with computers contributed significantly to the development of mathematical ability. However, gender and age did not appear to differentiate children's matehmatical competence.

For the acquisition/development of language and mathematical skills/concepts, different software/applications target young children; however, the boundaries between different applications are not necessarily fixed as different applications are presented in a form of play designed to attract and sustain children's attention (Nikolopoulou, 2007). Earlier research reported that the most commonly used programs were the MS Paint, commercial and educational CD-ROMs, the MS Word and the internet (Nikolopoulou, 2014b). For example, the integration of word-processing software into preschool classes has been shown to facilitate children's knowledge of print, experimental writing, and encourage child-to-child interactions (Åberg et al., 2014).

\section{Research Questions of the Study}

As stated earlier, the purpose of this study was to investigate early childhood teachers' practices of ICT-supported early language and mathematics learning. Two basic parameters/conditions for the study were: 1) the presence of at least one computer/laptop/tablet in the kindergarten classroom and its use by preschool children in language and mathematics, and 2) the voluntary participation of teachers. As stated earlier, mobile devices are also included within the term ICT. The following research questions were addressed:

1) What are the purposes-reasons for ICT usage in ECE classrooms?

2) What are teachers' practices in early language learning via ICT?

3) What are teachers' practices in early mathematics learning via ICT?

\section{Method}

\subsection{Sample}

The sample of the study consisted of eight teachers working in six public or pri- 
vate ECE settings, of similar socioeconomic status, in Athens, Greece. Table 1 shows the demographic characteristics of the sample (years of teaching experience, years of ICT use in class for educational purposes, teacher training in ICT) and characteristics of the settings (type of school, number and ages of children). All teachers were female, and this is the typical situation in ECE settings. It is noted that all these ECE settings have one computer with internet connection, while half of them also have an interactive whiteboard and a laptop.

\subsection{Procedure and Research Instrument}

The data were collected via semi-structured interviews with 8 teachers, between October 2019 and January 2020. Qualitative types of approaches are suitable and are often used in ECE settings (Nikolopoulou, 2010). A larger number of teachers were initially contacted but some of them were reluctant to participate. Teachers' participation was voluntary. Ethical issues were considered; all participants were assured that, should they wish to participate in the research, their comments and input would remain anonymous. Official permission was obtained from the University's ethics committee.

The interview questions were designed by the author for the purpose of this study, and were in line with the objectives of this study: What are the purposes-reasons for ICT usage in ECE classrooms? How is technology used in your classroom? What are your practices in early language via ICT? Which language skills do you aim to be acquired/exercised via the use of technology? Which programs are used in language? What are your practices in early mathematics via ICT? Which mathematical skills do you aim to be acquired/exercised via the use of technology? Which programs are used in mathematics? What are children's emotions when technology is used in the class? Additionally, information regarding teachers' demographic characteristics (years of teaching experience, years of ICT use in class for educational purposes, teacher training in ICT) and the settings' characteristics (type of school, number and ages of children) was

Table 1. Demographic characteristics of the sample and characteristics of settings.

\begin{tabular}{|c|c|c|c|c|c|}
\hline $\begin{array}{l}\text { Teacher } \\
\text { code }\end{array}$ & $\begin{array}{l}\text { Years of teaching } \\
\text { experience }\end{array}$ & $\begin{array}{l}\text { Years of ICT use } \\
\text { in class }\end{array}$ & $\begin{array}{c}\text { Teacher training } \\
\text { in ICT }\end{array}$ & $\begin{array}{l}\text { Type of } \\
\text { school }\end{array}$ & $\begin{array}{c}\text { Number (and ages) } \\
\text { of children }\end{array}$ \\
\hline $\mathrm{T} 1$ & $16-20$ & $1-4$ & B' level & full-day^ & 11 (aged $4-6)$ \\
\hline $\mathrm{T} 2$ & $11-15$ & $5-10$ & A' level & classic $^{\wedge} \wedge$ & $22($ aged $4-5)$ \\
\hline T3 & $20+$ & $5-10$ & B' level & classic & 22 (aged $4-6)$ \\
\hline $\mathrm{T} 4$ & $11-15$ & $5-10$ & A' level & classic & 24 (aged $4-5.5)$ \\
\hline T5 & $11-15$ & $5-10$ & A' level & classic & 22 (aged $4-5)$ \\
\hline T6 & $20+$ & $10+$ & B' level & full-day & 24 (aged $4-5)$ \\
\hline T7 & $1-10$ & $1-4$ & seminar & classic & 17 (aged $4-5)$ \\
\hline $\mathrm{T} 8$ & $20+$ & $10+$ & B' level & full-day & 22 (aged $4-6)$ \\
\hline
\end{tabular}

$\wedge$ full-day: children attend kindergarten from 8:30 a.m. - 4 p.m. $\wedge^{\wedge}$ classic: children attend kindergarten from 8:30 a.m. - 12:30 p.m. 
collected via relevant questions. Each interview lasted for about 12 - 15 minutes. The interviews were conducted in a quiet place of the setting, at a time period that did not disturb the participants' teaching duties; these were audio-recorded via a mobile phone by a student teacher.

With regard to content/thematic analysis, the codes for the data analysis were descriptive. Through the process of coding, patterns of responses were used to inform themes and categories generated in line with their relevance to the research questions (Creswell, 2012). Teachers' responses were thematically grouped into those which (predominantly) related to purposes-reasons for ICT usage in ECE classrooms, ICT-supported learning activities in early language and mathematics learning, as well as language and mathematical skills acquired/exercised via ICT.

\section{Results}

\subsection{Purposes-Reasons for ICT Usage in Class}

Table 2 indicates the purposes-reasons for ICT usage in classes, as these were reported by the teachers. The most commonly reported purposes were searching for information (6 references), as a supplementary-supportive tool (4 references) and displaying of educational video/pictures ( 4 references), followed by listening to music/songs, and enhancement of preschool subjects.

Excerpts regarding the purposes-reasons for ICT usage in class were: "It is also a tool that we use for searches on any topic. We search with the kids in the search engine for keywords on the topics they have to explore. They look and

Table 2. Purposes-reasons for ICT usage in classes.

\section{Purposes-reasons for ICT usage in classes}

Searching for information (e.g., video, pictures) 6

As a supplementary tool (e.g., for enhancement of skills) 4

Displaying of educational video/pictures 4

Listening to music/songs 2

Enhancement of pre-school subjects $\quad 1$

Collaboration/communication 1

Learning the keyboard 1

Way of usage

$\begin{array}{ll}\text { Hour of free activities } & 6\end{array}$

As supportive/complementary tool to the curriculum 4

As a teaching tool 2

Frequency of computer use in class

Daily

2 - 4 times per week 2

Once per month or less 1 
discover videos and pictures. They may do individual or group work and (may) want to print it; they have learned to send it to the (teachers') office" (T8); "The computer is used as an enhancive tool for teaching. We watch videos related to the topic we are working on and a program with educational games such as puzzles, letters and numbers. Also, (the computer is used) to search for information like we did for the olive tree" (T6); "The computer that is used by children is connected to the internet. This is used for supervisory/displaying purposes (supervisory tool, teaching aid). For example, for many things like boards, short videos, songs, as there is internet connection. We also use it for educational games that children play during the hour of free activities" (T4); "Children interact both with each other and with the laptop. They learn the keyboard and then (they) write some words on the laptop" (T7).

Regarding the way of ICT usage, it mainly happened in the hour of free activities (in 6 out of the 8 cases) and as a supportive/complementary tool to the programme of studies; 5 teachers reported using ICT daily. Examples of responses, regarding the way of ICT usage, as provided by the teachers included: "Computers are used by kids during leisure/free activities, but not from the beginning of the year, and also in support of the curriculum. In addition, we use the computer in our office for children's records and classroom organization" (T2); "It is used during free time by the service team. Each group has five children and each child uses the computer for 10 minutes per day" (T6); "It is used during free activities where we can put a song for the children to hear or something to see. We may listen to a fairy tale or play some games while listening. It is also used as a teaching aid for watching images" (T7).

Teachers were also asked as to which factors encourage them to use ICT in the classroom. Six out of eight reported that the lesson becomes more attractive (it attracts children's interest), three mentioned that children are familiar with the technology, while other references regarded the picture/sound, the ease of use, the multimodality of the medium. The following extracts were responses from the teachers: "I believe that image is a key factor, as is movement. In addition, I believe that these children were born into the world of image and sound, that is, into the world of digital reality. Thus, the computer attracts their interest and they can watch better...It has also an instructional character. For example, when we search for something, they see a different use of the computer; it is not only a gaming machine for leisure but also for searching and learning things" (T4); "It's a fun medium for kids to enjoy. The image motivates them to participate. The computer is now familiar to children" (T7); "I primarily use ICT because it is mandatory from the curriculum. I also believe that technology has an added value and the computer attracts children's interest. But I do not think that everything should be replaced by computers. I definitely believe that the computer is a multimodal means to enrich students' knowledge" (T2); "Children today are very familiar with it (digital technology), it is pleasant for them and fun to use" (T8). 
The teachers were also asked about children's emotions/feelings when ICT is used in the classroom. It is noteworthy that all teachers mentioned children's positive feelings, such as joy and enthusiasm. Examples of excerpts were: "The children like it very much and they do it with great pleasure", "Children are happy when they are going to use the computer", and "They get excited and (they) do not lose interest as we do not use it much".

\subsection{Teachers' Practices in Early Language Learning via ICT}

Table 3 indicates teachers' practices in early language learning via ICT. The learning activities carried out regarded displaying of pictures/drawings (6 references), writing a word/name/date (5 references), practicing letters, connecting words to their sound/image, phonological awareness etc. Teachers reported a range of language skills they believe to be acquired or exercised via ICT use: familiarization with the written word/reading/oral language, enhancement of vocabulary and learning the letters. Regarding the programs used these were the word-processor, educational CD-ROMs, PowerPoint and the internet.

Excerpts regarding teachers' practices in early language learning (including language skills development) via ICT were: "These (language activities) take

Table 3. Teachers' practices in early language learning via ICT.

\section{Learning activities in language via ICT}

Displaying of pictures/drawings $\quad 6$

Writing a word/text/date/names $\quad 5$

Educational videos-practicing letters 3

Connecting words with their sound/picture 3

Phonological awareness 2

Creation of a poster/invitation 2

Listening to a tale/song 2

Recognition of letters, displaying letters 2

Language skills acquired/exercised via ICT

Familiarization with the written word 3

Familiarization with reading, oral language/speech 2

Enhancement of vocabulary 2

Learning the letters as symbols $\quad 2$

$\begin{array}{ll}\text { Cognitive skills, collaboration } & 2\end{array}$

Programs used in language

$\begin{array}{ll}\text { Word-processor } & 7\end{array}$

$\begin{array}{ll}\text { CD-ROM } & 6\end{array}$

$\begin{array}{ll}\text { Power-point } & 4\end{array}$

Educational software (installed in computer) 4

Internet 3 
place every day, as language is everywhere. They (children) do activities that combine words with objects, recognize letters and put them in order/sequence to make a word...Vocabulary enrichment, sentence writing, familiarity with written and spoken language. We provide opportunities for them to practice speaking, communicating and thinking" (T8); "Children use the computer in groups of two so that there is communication and cooperation. Activities carried out include phonemic awareness, audio-letter connection, filling in the missing letter, and games related to familiarizing children with the written word and listening to the sounds" (T3); "There is also the possibility for children to make a poster on the computer, with the guidance of the teacher. They can write a text, listen to a song, watch a video, read a fairy tale and then listen to it, take pictures or even see paintings and later describe them" (T2); "I have found some educational videos (a practice we followed last year as well) where children come in contact with letters, phonetically. Therefore, depending on which letter we were working on, we practiced correlating the voices to the letters. They (children) watched the corresponding video and when it was over, it did not last more than five minutes, we discussed what words they heard from the phoneme we had worked on and we also recorded the words" (T1); "Children, I believe, that by looking at the keyboard and learning to type or copy words, they become familiar with the written code" (T7); "I believe that children become familiar with the sounds/phonems and the written word" (T4). A teacher (T3) who is not using ICT often for language activities stated: "I do not often use the computer for language activities. I use worksheets for such activities".

\subsection{Teachers' Practices in Early Mathematics Learning via ICT}

Table 4 indicates teachers' practices in early mathematics learning via ICT. The learning activities carried out regarded seriation/sorting of objects, learning of time and/or space concepts, familiarization with numbers, classification, matching (e.g., numbers with number of objects), as well as various activities with shapes, colors, memory cards, and songs with numbers. Teachers reported a range of mathematical skills they believe to be acquired or exercised via ICT: familiarization with quantitative concepts, with shapes/colors, with space concepts, and first acquaintance with addition and subtraction. Educational CDROMs were reported to be used by all teachers in mathematics.

Excerpts regarding teachers' practices in early mathematics learning (including mathematical skills development) via ICT were: "Mathematical activities involve sorting objects, matching and getting acquainted with numbers" (T5); "Children become familiar with the concepts of space, colors, numbers, shapes and quantity. When they did the activity with the paintings the children tried to identify the shapes, they have created pictures with the help of the puzzle, they got acquainted with the meaning of the line through a book they made" (T2); "Seriations, classifications and games with concepts such as more-less, up-down, concepts related to quantity and space" (T4); "Kids become familiar with concepts 
Table 4. Teachers' practices in early mathematics learning via ICT.

\begin{tabular}{ll}
\hline Learning activities in mathematics via ICT & 4 \\
Seriation of objects & 3 \\
Learning of time and/or space concepts & 3 \\
Familiarization/learning of numbers & 3 \\
Classification (e.g., of objects) & 3 \\
Matching (e.g., numbers with number of objects) & 3 \\
Shapes, colors, memory cards, songs with numbers & \\
Mathematics skills acquired/exercised via ICT & 7 \\
Familiarization with numbers & 7 \\
Familiarization with quantitative concepts & 6 \\
Familiarization with shapes/colors & 5 \\
Familiarization with space concepts & 2 \\
First acquaintance with counting, addition/subtraction & 2 \\
Learning of (designing) lines & 1 \\
Programs used in mathematics &
\end{tabular}

such as smaller-larger, left-right, up and down, as well as numbers" (T6); “There are songs with numbers, games with numbering of objects and with spatial and quantitative concepts, observation of images... Kids become familiar with the concepts of space, colors, numbers, shapes and quantity. They come in contact with numbers, with the operations of subtraction and addition. Even the observation of some phenomena that are difficult to be explained in the classroom" (T1); "In mathematics, which is easier, we insert a Table, make a shape or play a game that has to do with shapes, colors, numbers... Children become familiar with quantitative concepts, the meanings of shapes and numbers" (T7); "Children become familiar with and develop observation and memory skills. They become familiar with recognizing shapes, numbers and concepts of quantity" (T8).

\section{Discussion and Conclusion}

The data of this study cannot be generalized due to the small sample and its origin from one region. However, the interviews with the teachers revealed some issues difficult to be explored through large-scale quantitative surveys. Taken into account that in Greece similar research in on increase, this study contributes to our understanding of ICT-supported early language and mathematics learning in kindergartens.

With regard to the first research objective, the most commonly reported reasons for using ICT in ECE classrooms were searching for information, as a sup- 
plementary tool and displaying of educational videos/pictures. The reasons given by the teachers were, in general, in agreement with the suggestions of the Greek curriculum and of NAEYC \& FRC (2012) recommendations; the use of technology is a tool to support, complement and extend classroom learning and children's engagement. There is an agreement with earlier studies which indicated as reasons for computer use the acquisition/development of language and mathematical skills, children's motivation (Nikolopoulou, 2014a), as well as the technology as supportive-complementary learning tool (Nikolopoulou, 2014a; Gray et al., 2017; Romero-Tena et al., 2020). There is also an agreement as to that technology use took place, mainly, during the hour of free activities/play (Ljung-Djärf, 2008; Nikolopoulou, 2014a, 2014b; Nikolopoulou \& Gialamas, 2015).

With regard to the second research objective, the learning activities carried out in early language with the support of ICT regarded displaying of pictures/ drawings, writing a word/name/date, practicing letters, connecting words to their sound/image, phonological awareness etc; such activities were reported to help children develop/exercise language skills such as familiarization with the written word, oral language, enhancement of vocabulary and learning the letters. There is an agreement with previous studies with regard to phonological awareness (Reeves et al., 2017), reading and writing skills (Gray et al., 2017; Åberg et al., 2014).

With regard to the third research objective, the learning activities carried out in early mathematics with the support of ICT included seriation/sorting of objects, learning of time and space concepts, familiarization with numbers, classification, matching, as well as activities with shapes, colors, memory cards, etc; these activities aim to help children develop/exercise mathematical skills such as familiarization with quantitative concepts, shapes/colors, space concepts, and first acquaintance with addition and subtraction. There is an agreement with earlier research with regard to activities and skills related to basic math skills such as classification, seriation, counting, and understanding of numbers (Papadakis et al., 2018; Zaranis \& Valla, 2019).

In general, the programs used in early language (word-processor, educational CD-ROMs, PowerPoint and the internet) and early mathematics (educational CD-ROMs) are in line with the national curriculum and with earlier research which reported that the most commonly used programs were the MS Paint, commercial and educational CD-ROMs and the MS Word (Nikolopoulou, 2014b).

This study's findings support the essential role of the teacher(s) in the whole process of ICT use-implementation in ECE classrooms. Digital technology has the potential to support young children's classroom experiences, but for this to happen it is important for teachers to carefully plan for, and articulate to children, suitable learning tasks. ICT usage does not necessarily leads to better learning outcomes; e.g., a recent study in preschools (Furman et al., 2019) indicated no significant difference between the tablet-enhanced classrooms and those taught without ICT. The essential importance of teacher's role towards more effective 
ICT integration in ECE settings has implications for (pre-service and in-service) teacher training. Early childhood teachers' skills-competencies to integrate technology effectively and their beliefs are all important in the process of computer integration-use in ECE settings. Early childhood teacher educators provide a critical link in helping the early childhood field move into the $21^{\text {st }}$ century and they should take the lead in preparing future teachers to use technology with children in responsible and developmentally appropriate ways. This study has social and practical implications. Teacher training is a major issue, but also school infrastructure is important; for example, ICT resources and the existence of developmetally appropriate software are needed in preschool ICT-supported environments.

Limitations of this study include the small sample size and the collection of data only via interviews. In the future, it is planned to carry out classroom observations of teachers' ICT-supported practices in ECE classrooms. Further research is needed on the learning activities being practiced with specific ICT tools-applications to assist early language and mathematics learning in young children (ICT-enhanced activities), and broadly on technology-mediated interventions. The issue of using technology in appropriate ways (Parette \& Blum, 2013) needs further investigation, as well as what encourages/motivates a teacher to use ICT in early years classroom. Digital technologies (including mobile technologies) are constantly/rapidly changing, while today's children, born into the digital world, are native speakers of technology, fluent in the digital language of computers, video games and the internet. The pedagogical issues of using digital technologies in early childhood education do not change rapidly, but it cannot be assumed that they remain constant either. Further research is needed, (inter)nationally, into early childhood pedagogy and ICT.

\section{Acknowledgements}

The author would like to thank the teachers who participated voluntarily in this study and the student teacher who conducted the interviews.

\section{Conflicts of Interest}

The author declares no conflicts of interest regarding the publication of this paper.

\section{References}

Åberg, E., Lantz-Andersson, A., \& Pramling, N. (2014). “Once upon a Time There Was a Mouse”: Children's Technology-Mediated Storytelling in Preschool Class. Early Child Development and Care, 184, 1583-1598. https://doi.org/10.1080/03004430.2013.867342

Clements, D. (1994). The Uniqueness of the Computer as a Learning Tool: Insights from Research and Practice. In J. Wright, \& D. Shade (Eds.), Young Children: Active Learners in a Technological Age (pp. 31-49). Washington DC: National Association for the Education of Young Children.

Clements, D., \& Sarama, J. (2003). Strip Mining for Gold: Research and Policy in Educa- 
tional Technology-A Response to "Fool's Gold”. Educational Technology Review, 11, 7-69.

Creswell, J. W. (2012). Educational Research: Planning, Conducting, and Evaluating Quantitative and Qualitative Research (4th ed.). Boston, MA: Pearson.

Dorouka, P., Papadakis, S., \& Kalogiannakis, M. (2020). Tablets and Apps for Promoting Robotics, Mathematics, STEM Education and Literacy in Early Childhood Education. International Journal of Mobile Learning and Organization, 14, 255-274. https://doi.org/10.1504/IJMLO.2020.106179

Furman, M., De Angelis, S., Dominguez Prost, E., \& Taylor, I. (2019). Tablets as an Educational Tool for Enhancing Preschool Science. International Journal of Early Years Education, 27, 6-19. https://doi.org/10.1080/09669760.2018.1439368

Gray, C., Dunn, J., Moffett, P., \& Mitchell, D. (2017). Mobile Devices in Early Learning: Evaluating the Use of Portable Devices to Support Young Children's Learning. Report commissioned by Irish Education Authority.

Herodotou, C. (2017). Young Children and Tablets: A Systematic Review of Effects on Learning and Development. Journal of Computer Assisted Learning, 34, 1-9.

https://doi.org/10.1111/jcal.12220

Kucirkova, N., Messer, D., Sheehy, K., \& Fernández Panadero, C. (2014). Children's Engagement with Educational iPad Apps: Insights from a Spanish Classroom. Computers \& Education, 71, 175-184. https://doi.org/10.1016/j.compedu.2013.10.003

Ljung-Djärf, A. (2008). To Play or Not to Play-That Is the Question: Computer Use within Three Swedish Preschools. Early Childhood and Development, 19, 330-339. https://doi.org/10.1080/10409280801964069

Lu, Y.-H., Ottenbreit-Leftwich, A. T., Ding, A.-C., \& Glazewski, K. (2017). Experienced iPad-Using Early Childhood Teachers: Practices in the One-to-One iPad Classroom. Computers in the Schools, 34, 9-23. https://doi.org/10.1080/07380569.2017.1287543

McKenney, S., \& Voogt, J. (2012). Teacher Design of Technology for Emergent Literacy: An Explorative Feasibility Study. Australasian Journal of Early Childhood, 37, 4-12. https://doi.org/10.1177/183693911203700102

National Association for the Education of Young Children (NAEYC), \& Fred Rogers center (FRC) (2012). Technology and Interactive Media as Tools in Early Childhood Programs Serving Children from Birth through Age 8.

http://www.naeyc.org/content/technology-and-young-children

Neumann, M. M. (2018). Using Tablets and Apps to Enhance Emergent Literacy Skills in Young Children. Early Childhood Research Quarterly, 42, 239-246. https://doi.org/10.1016/j.ecresq.2017.10.006

Neumann, M. M. (2020). Social Robots and Young Children's Early Language and Literacy Learning. Early Childhood Education Journal, 48, 157-170. https://doi.org/10.1007/s10643-019-00997-7

Neumann, M. M., Merchant, G., \& Burnett, C. (2018). Young Children and Tablets: The Views of Parents and Teachers. Early Child Development and Care, 188, 1654-1664. https://doi.org/10.1080/03004430.2016.1278215

Nikolopoulou, K. (2007). Early Childhood Educational Software: Specific Features and Issues of Localization. Early Childhood Education Journal, 35, 173-179. https://doi.org/10.1007/s10643-007-0168-5

Nikolopoulou, K. (2010). Methods for Investigating Young Children's Learning and Development with Information Technology. In A. McDougall, J. Murnane, A. Jones, \& N. Reynolds (Eds.), Researching IT in Education: Theory, Practice and Future Directions (pp. 183-191). London: Routledge. 
Nikolopoulou, K. (2014a). ICT Integration in Preschool Classes: Examples of Practices in Greece. Creative Education, 5, 402-410. https://doi.org/10.4236/ce.2014.56050

Nikolopoulou, K. (2014b). Educational Software Use in Kindergarten. In C. Karagiannidis, P. Politis, \& I. Karasavvidis (Eds.), Research on e-Learning and ICT in Education: Technological, Pedagogical and Instructional Perspectives (pp. 39-57). New York: Springer. https://doi.org/10.1007/978-1-4614-6501-0 4

Nikolopoulou, K. (2018 new enhanced edition). Information and Communication Technologies in Early Childhood Education: Integration and Use. Athens: Patakis. (In Greek)

Nikolopoulou, K. (2019). Mobile Technologies and Early Childhood Education. In M. Tsitouridou, J. A. Diniz, \& T. Mikropoulos (Eds.), Technology and Innovation in Learning, Teaching and Education. TECH-EDU 2018. Communications in Computer and Information Science (pp. 444-457). Cham: Springer.

https://doi.org/10.1007/978-3-030-20954-4 33

Nikolopoulou, K. (2020). Preschool Children's Use of Tablet at Home and Parents' Views. In S. Papadakis, \& M. Kalogiannakis (Eds.), Mobile Learning Applications in Early Childhood Education (pp. 209-229). Hershey, PA: IGI Global. https://doi.org/10.4018/978-1-7998-1486-3.ch011

Nikolopoulou, K., \& Gialamas, V. (2015). ICT and Play in Preschool: Early Childhood Teachers' Beliefs and Confidence. International Journal of Early Years Education, 23, 409-425. https://doi.org/10.1080/09669760.2015.1078727

Nikolopoulou, K., Akriotou, D., \& Gialamas, V. (2019). Early Reading Skills in English as a Foreign Language via ICT in Greece: Early Childhood Student Teachers' Perceptions. Early Childhood Education Journal, 47, 597-606. https://doi.org/10.1007/s10643-019-00950-8

Ofcom (2019). Children and Parents: Media Use and Attitudes Report 2018. Making Sense of Media.

Outhwaite, L. A., Gulliford, A., \& Pitchford, N. J. (2017). Closing the Gap: Efficacy of a Tablet Intervention to Support the Development of Early Mathematical Skills in UK Primary School Children. Computers \& Education, 108, 43-58.

https://doi.org/10.1016/j.compedu.2017.01.011

P.I (2011). Nursery School Program, Part 1, Pedagogical Framework and Principles of the Nursery School Program.

http://archive.is/20121218094948/digitalschool-5.minedu.gov.gr/info/newps.php

Papadakis, S., \& Kalogiannakis, M. (Eds.) (2020). Mobile Learning Applications in Early Childhood Education. Hershey, PA: IGI Global.

https://doi.org/10.4018/978-1-7998-1486-3

Papadakis, S., Kalogiannakis, M., \& Zaranis, N. (2016). Comparing Tablets and PCs in Teaching Mathematics: An Attempt to Improve Mathematics Competence in Early Childhood Education. Preschool and Primary Education, 4, 241-253. https://doi.org/10.12681/ppej.8779

Papadakis, S., Kalogiannakis, M., \& Zaranis, N. (2018). The Effectiveness of Computer and Tablet Assisted Intervention in Early Childhood Students' Understanding of Numbers. An Empirical Study Conducted in Greece. Education and Information Technologies, 23, 1849-1871. https://doi.org/10.1007/s10639-018-9693-7

Parette, H., \& Blum, C. (2013). Instructional Technology in Early Childhood: Teaching in the Digital Age. Baltimore, MD: Brookes.

Reeves, J., Gunter, G., \& Lacey, C. (2017). Mobile Learning in Pre-Kindergarten: Using Student Feedback to Inform Practice. Educational Technology \& Society, 20, 37-44.

Romero-Tena, R., Lopez-Lozano, L., \& Gutierrez, M. P. (2020). Types of Use of Technol- 
ogies by Spanish Early Childhood Teachers. European Journal of Educational Research, 9, 511-522. https://doi.org/10.12973/eu-jer.9.2.511

Stephen, C., \& Edwards, S. (2018). Young Children Playing and Learning in a Digital Age: A Cultural and Critical Perspective. London: Routledge. https://doi.org/10.4324/9781315623092

Stephen, C., \& Plowman, L. (2003). Information and Communication Technologies in Pre-School Settings: A Review of the Literature. International Journal of Early Years Education, 11, 223-234. https://doi.org/10.1080/0966976032000147343

Zaranis, N., \& Valla, V. (2019). Tablets in Learning Mathematics for Kindergarten Students. In L. Daniela (Ed.), Didactics of Smart Pedagogy (pp. 267-284). Cham: Springer. https://doi.org/10.1007/978-3-030-01551-0 14 